\title{
Off-Farm Labor Supply and Fertilizer Use
}

\author{
Russell L. Lamb \\ Federal Reserve Board \\ Mail Stop 80 \\ 20th and C Streets, NW \\ Washington, DC 20551
}

\begin{abstract}
I develop a two-period stochastic dynamic programming model to explain the interaction between fertilizer use and off-farm labor supply. I use a well-known sample of farmers in the semi-arid tropics of India to test the model. I find that fertilizer use responds strongly to wages in the village labor market and that irrigation raises fertilizer use, while larger farmers use less fertilizer than smaller ones. Response to one-sided production shocks, which measure effects of negative weather on labor supply, are particularly strong for female labor, indicating that it is more important for smoothing consumption than male labor.
\end{abstract}

Acknowledgements: I thank Jere Behrman, Andrew Foster, Mark Rosenzweig, Emmanuel Skoufias and participants at the 1995 Summer meetings of the American Agricultural Economics Association for helpful discussions on the model and the ICRISAT data. The views reflected are the author's and not those of the Federal Reserve Board or its staff. 


\section{Introduction}

The primary means of "getting agriculture moving," and thus raising rural incomes, in developing countries has been the diffusion of new production techniques, especially highyielding varieties of seeds, chemical fertilizers, and pesticides. A major impediment to the adoption of such modern inputs has been thought to be the well-documented risk-aversion on the part of rural decision makers in developing countries (Moscardi and de Janvry (1977), Binswanger (1980, 1981) and Antle (1987, 1989)). Risk averse farmers will try to smooth consumption with both ex-ante ${ }^{1}$ and ex-post mechanisms.

The role of ex-post consumption smoothing and its effect on various aspects of rural household behavior is well documented. Rosenzweig and Wolpin (1993) show that sales of farm assets (e.g. bullocks) are used to smooth consumption by farmers whose income is lowered by a negative production shock. Rose (1994) shows that ex-post labor supply responds to weather shocks. Rosenzweig shows that inter-village transfers of wealth by family members are used to smooth consumption across villages. Townsend (1994) and Paxon (1993) show that household level consumption is largely explained by village-level consumption patterns, indicating that agents smooth most of the idiosyncratic shocks to income within the village.

Ex-ante mechanisms for risk mitigation, such as insurance, are not widespread in developing countries, and might be hard to implement in agrarian economies because of moral hazard problems. ${ }^{2}$ To the extent that consumption risk is imperfectly insured, farmers' ex-

\footnotetext{
${ }^{1}$ Ex-ante refers to the period before the uncertainty concerning yields has been resolved, and ex-post the period after uncertainty about crop yields is resolved.

${ }^{2}$ Nor, for that matter, are insurance mechanisms widely utilized among farmers in many developed economics. In many developed economies, the government acts as a sort of de
} 
ante choices will be distorted by risk-aversion. For example, Rosenzweig and Binswanger (1993) show that farmers in more risky areas deviate more from the optimal portfolio of assets, and that this deviation is worse among poorer farmers than wealthier ones. Indeed, risk aversion has been argued to play an important role in inhibiting the spread of modern inputs (Feder, Just and Zilberman, 1985). Moreover, the risk-increasing role of modern inputs exacerbates the effect of risk aversion on production choices. For example, Rosenzweig and Shaban (1994) show that farmers use share-tenancy contracts to spread the risk of new seeds when they are first introduced and their cultivation properties are still uncertain. To the extent that farmers choose traditional inputs, such as organic fertilizers and traditional seeds, over modern inputs in order to lower their ex-ante risk, then any mechanism that allows farmers to smooth consumption ex-post will raise the use of modern inputs and increase farmer productivity. Moreover, ex-post choices should respond to shocks in a way that depends on ex ante choices. There are important distributional effects to such improvements, since poorer farmers are generally thought to be more risk-averse than wealthy farmers and so their choices will be more affected by exposure to risk.

I argue in this paper that farm households use off-farm labor supply to mitigate the effects of production shocks ex-post, and this leads to more efficient ex-ante production choices on the part of farmers, in particular greater use of chemical fertilizer. The organization of the paper is as follows: In Section II, I develop a two-period, stochastic dynamic programming model of a risk-averse, expected utility maximizing farmer who chooses the level of modern input and off-farm labor supply, and discuss the comparative

facto insurer. 
static results of the model. In Section III, I discuss the ICRISAT data set briefly and describe the variables used to test the model. In Section IV, I present estimates of fertilizer demand and off-farm labor supply which show that off-farm labor supply responds more sharply to the weather shock for farmers who use chemical fertilizers than for those who do not. Section $\mathrm{V}$ concludes.

\section{Theoretical Model}

Consider an expected-utility -maximizing farmer who produces a single crop over a two-period (intra-year) crop cycle. ${ }^{3}$ Assume that the farmer's preferences are characterized by a strictly concave utility function, $\mathrm{U}(\mathrm{I})$; U' $>0$, U' $\mathrm{O}$, where I is total income. Production decisions are made in two distinct periods, which are identified by a random production shock, O. It is most appropriate to think of the shock as measuring the timing and quantity of rainfall, although in some contexts a broader definition of weather uncertainty which incorporates temperature or natural disasters (such as hurricanes, volcanoes, etc.) might be more appropriate. The shock, which is fully known at the beginning of the second period, has mean $\theta$, and a random component, $\tilde{\theta}$, which the farmer cannot forecast using information available in the first period. In the first period, the farmer chooses the quantity of fertilizer, $\mathrm{X} .{ }^{4}$ In the second period the farmer allocates household labor between labor used in crop production (1) and off-farm labor supply (L). The decision process is described schematically in Figure 1.

${ }^{3}$ This model is similar in spirit to that of Rose (1994) and Saha (1994).

${ }^{4}$ If labor use is proportional to fertilizer use in the first period, then omitting labor choice from the first-period problem will not bias the results. 
Figure 1

Rainfall uncertainty resolved

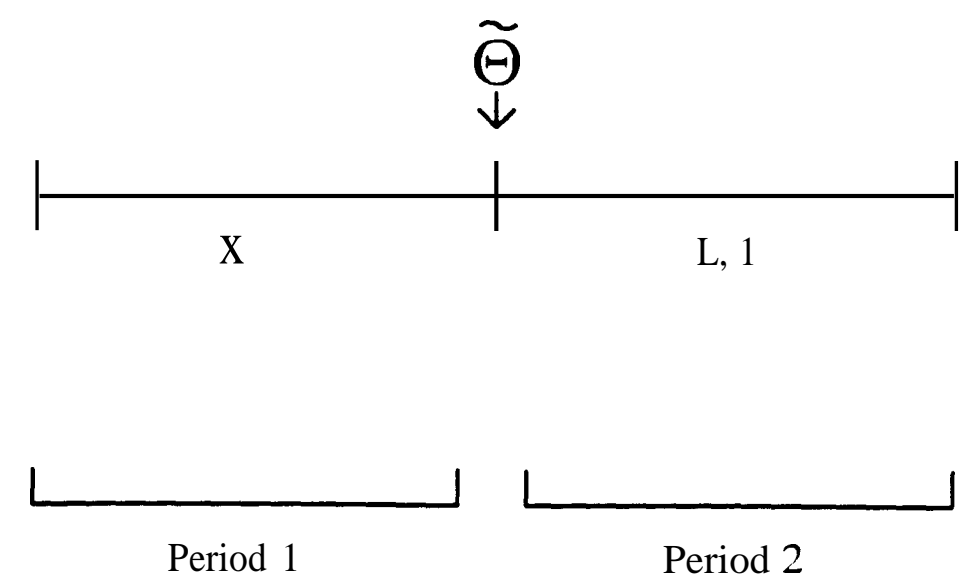


The household's labor constraint is given by:

$$
\mathrm{L}+1=\overline{\mathrm{L}}
$$

where $\mathrm{L}$ is off-farm labor supply, ${ }^{5} 1$ is production labor, and $\overline{\mathrm{L}}$ is total labor endowment. The single good is assumed to be perfectly storable between the end of period two and the beginning of period one, but to decay completely at the end of period one, so that there is no discussion of storage problems. Let $\mathrm{Q}$ denote output. The production technology is given in (2):

$$
Q=\left[\gamma \bar{\theta}+(1-\gamma)^{\lambda} \tilde{\theta}\right] f(X, \bar{L}-L)
$$

where $\mathrm{X}$ is fertilizer; $\overline{\mathrm{L}}-\mathrm{L}$ is labor used in crop production, substituting in the constraint in

(1); $\gamma$ is the share of irrigated land; the parameter $\lambda>0$ measures the effect of irrigation

on the response to the rainfall shock; $f(X, L-L)$ has the properties of a neoclassical production

function: $\mathrm{f}_{\mathrm{x}}>0, \mathrm{f}_{\mathrm{l}}>0, \mathrm{f}_{\mathrm{xl}}>0, \mathrm{f}_{\mathrm{xx}}<0, \mathrm{f}_{\mathrm{ll}}<0$. Equation (2) decomposes the effect of weather into its mean and shock components. The random shock $\tilde{\theta}$ is assumed to be i.i.d. across time with finite variance. The level of irrigation, $y$, increases mean output in a way that depends on the expected value of the weather shock, $\overline{0}$, while the effect of the purely random component, $\tilde{\theta}$ also depends on $\mathrm{y}$, through the parameter $\lambda$.

The weather shock affects the wage earned in the off-farm labor market. Positive

\footnotetext{
${ }^{5}$ The term "off-farm' refers to any work performed outside of the households own agricultural production activities, whether that work is in the agricultural or nonagricultural sector. In fact, much of the off-farm work performed in the ICRISAT villages studied below is in fact on another farm.
} 
weather shocks increase the demand for labor in the local labor market, raising the wage. The effect of the weather shock on wages depends on the share of non-agricultural employment in the local labor market, which we denote by $\mathrm{d}$. The wage faced by the farmer reflects labor market conditions in both agricultural and nonagricultural employment, and depends on the village average wage and other factors:

$$
\mathrm{w}=\overline{\mathrm{w}}+\tilde{\theta} \mathrm{d} \eta
$$

where the index for the village has been suppressed on $\bar{w}$. The parameter $\eta>0$ captures the effect of the non-agricultural employment on the wage received by the farmer. The input price is $\mathrm{q}$, and output price is normalized to one. The farmer's profits are:

$$
\pi=\left[\gamma \bar{\theta}+(1-\gamma)^{\lambda} \tilde{\theta}\right] \mathrm{f}(\mathrm{X}, \overline{\mathrm{L}}-\mathrm{L})-\mathrm{qX}+\left(\overline{\mathrm{w}}+\tilde{\theta} \mathrm{d}^{\eta}\right) \mathrm{L}
$$

The farmer uses the standard dynamic programming algorithm to solve the maximization problem (Intrilligator, 1971). He first solves the second period problem by choosing the optimal allocation of labor between farm production and off-farm labor supply in the second period, conditional on his choice of fertilizer in the first period and the realization of the production shock. Since there is no uncertainty, the farmer's problem is to maximize profits. The first-order condition for the second-period maximization problem is given in (5):

$$
-\left[(1-\gamma)^{\lambda} \tilde{\theta}+\gamma \bar{\theta}\right] f_{1}(X, \bar{L}-L)+\left(\overline{\mathrm{w}}+\tilde{\theta} \mathrm{d}^{\eta}\right)=\mathrm{O}
$$

Derivations of comparative static results are relegated to the appendix. Off-farm labor supply decreases with increases in the random component of the shock $(\tilde{\theta})$ if the effect of the shock on the marginal product of labor is greater than its effect on the wage received for offfarm work. Increases in the average wage always increase labor supply, by the second-order conditions. Off-farm labor supply decreases with increases in fertilizer use if $f_{x l}>0$, e.g. if 
fertilizer and production labor are complements. An increase in the farmer's share of irrigated land has an effect on labor supply that depends on the realization of the weather shock. For a negative weather shock, the farmer always supplies less labor off-farm the larger is his share of irrigated land.

A major conjecture in the above model is that farmers use ex-post responses to mitigate the effect of ex-ante decisions. So we expect an important interaction between various parameters affecting ex-ante decisions and second-period labor supply, e.g. $\partial^{2} \mathrm{~L} / \partial \tilde{\theta} \partial \mathrm{X}$. The interaction between the realization of weather uncertainty and fertilizer use depends on the third derivative of the production function, $\mathrm{f}_{11 \mathrm{X}}$. A necessary condition for $\partial^{2} \mathrm{~L} / \partial \tilde{\theta} \partial \mathrm{X}<0$ to hold is $\mathrm{f}_{11 \mathrm{x}}<0$, although the sign cannot be determined a priori without placing more stringent restrictions on the parameters. In addition, we may consider the second order effects of various parameterizations on the response to the production shock. The effects of the production shock on off-farm labor are less important the greater the share of irrigated land if the shock is "small" and if the shock affects the marginal product of labor more than the wage in the off-from labor market.

In the first period, the farmer chooses the quantity of fertilizer to maximize the expected utility of profits, $\mathrm{E}_{\theta}\{\mathrm{U}(\pi)\}$. The first-order condition is:

$$
\mathrm{E}_{\theta} \mathrm{U}^{\prime}\left\{\left[\gamma \overline{\boldsymbol{\theta}}+(1-\gamma)^{\lambda} \tilde{\theta}\right] \mathrm{f}_{\mathrm{x}}-\mathrm{q}\right\}=\mathrm{O}
$$

The farmer under-utilizes fertilizer, in the sense that the expected marginal product of fertilizer is greater than its price. Thus expected profits could be raised by increasing fertilizer use. A result of the dynamic structure of the model is that comparative statics for 
the first-period variable must consider the effect on second-period variables, as farmers adjust their production labor in light of changes in the quantity of fertilizer used. With this in mind, the quantity of fertilizer demanded decreases with increases in the price of fertilizer and with increases in the variability of the weather shock, as measured by a mean-preserving spread in the distribution. Increases in d--the share of nonagricultural employment in the local labor market--raise fertilizer use, since they make the second period wage less susceptible to the shock. The effects of increases in the second-period wage are indeterminate, but can yield increases in fertilizer use under fairly strong assumptions. The response of fertilizer demand to increases in the share of irrigated land yield is probably positive, but it depends on the response of second period labor supply. Increases in mean rainfall raise fertilizer demand.

\section{Production in the Semi-Arid Tropics of India and the ICRISAT Panel}

I use a widely discussed data set collected by the International Crop Research Institute for the Semi-Arid Tropics (ICRISAT) from the semi-arid tropics of India (SAT) to test the model outlined above. ${ }^{6}$ Data were collected from forty farmers, approximately thirty of whom were cultivators, in ten different Indian villages representing three distinct regions of India's SAT over the period 1975 to $1984 .^{7}$ I focus on the three "primary" study villages--

'See, for example, Rosenzweig and Binswanger (1993) and Skoufias (1994), for some interesting uses of the same data. The data are described in detail in Walker and Ryan (1986).

${ }^{7}$ Data are available from three of the study villages for ten years; three other original villages were studied for a shorter time period then dropped; data on two other villages is available for four years and two of the villages were sampled for only two years. However, complete data on assets were not collected for 1975 and 1984, so I dropped those years from my sample. Data on time specific wages were only available through 1976-1977 for some of the initial villages, and those were dropped as well. 
Aurepalle, Shirapur and Kanzara--and two villages added to the sample in 1980: Boriya and Rampura. The villages of Papda and Rampura Kalan were dropped from the sample because they didn't report any use of fertilizers during the sample period.

Agricultural production in the semi-arid tropics is characterized by two main growing seasons. The rainy (kharif) season begins with the onset of the monsoon when soils are waterrich and germination is easy. The post-rainy (rabi) season, which is somewhat less important in overall agriculture, begins after the monsoon, drawing on moisture stored in the soil after rainy-season crops have been grown. The model of pre- and post-shock decision-making is appropriate only for kharif crops; it is a poor description of decision-making for dry season crops. Moreover, weather is a major source of the uncertainty surrounding households' production environment and can be easily summarized by the timing and amount of rainfall. Crop yields are highly susceptible to variations in the timing and duration of the monsoon. Rosenzweig and Binswanger (1993) found that household profits from crop production are correlated with the monsoon onset date and Skoufias (1994) found total agricultural output to be strongly dependent on the monsoon onset as well.

The ICRISAT data set is well-suited to considering the effect of ex-post risk mitigation on ex-ante decision making because it contains information on the timing of production and labor supply choices by the household, which allows ex-ante decisions to be disentangled from ex-post decisions. ${ }^{8}$ Time-specific wage information allows identification of the pre-shock and post-shock wages as well. This ability to identify pre-shock and post-shock

'In Lamb (1994), I consider the possibility of identifying ex-post decisions from annual data, but those results are less than satisfying. 
wages allows for identification of the separate effects of the wages realized on the farmer's decision to use modern inputs and allows for the separate estimation of ex-ante and ex-post labor supply. Finally, the regions covered by the ICRISAT data set have seen the introduction of high-yielding varieties of some crops, improved technology for irrigation, and chemical fertilizers, with varying degrees of success.

Table I contains a listing of the variables used in estimation. To construct household labor supply, I used Rosenzweig and Binswanger's (1993) definition of the monsoon onset and end dates to distinguish between activities that occurred before the end of the monsoon -period one in the model -- and those that occurred after the monsoon ended -- period two in the model. Off-farm labor supply is average hours worked per day in all activities not related to production on the respondents own plots, including farm work for others and nonfarm work. Period-specific village-average wages were defined using information on time and type of task: I used the wage for crop work reported in the early part of the sample and the wage for agricultural work in the second half of the sample. ${ }^{9}$ The wage in agriculture is divided by the village-level consumer price index to create the real village-level wage (Walker and Ryan, 1990, p. 28). I distinguish between the pre-shock and post-shock wages using monsoon onset and end dates from Rosenzweig and Binswanger. The real price of chemical fertilizer in the village is calculated similarly. Total area farmed by the household includes

\footnotetext{
${ }^{9}$ The structure of the ICRISAT questionnaire changed in 1979; from 1975 to 1978 respondents were asked how many hours they worked the previous day in various activities. After 1978 households were asked how many hours they had worked since the last interview. This necessitated some adjustment in how I created labor supply variables: After 1978 I constructed average daily labor supply (in hours) by dividing total hours worked by the number of days in the sample period.
} 
sharecropped, rented and owned land, and accounts for double cropping, an important practice among the ICRISAT households. The share of total cropped area that is irrigated affects the shock's impact on output. Several different rainfall variables, measured as the deviation from the village average (as well as their interactions with other variables) were used in estimation, including: the monsoon onset date, the monsoon end date, the frequency of days during the monsoon which experienced some rainfall, and total rainfall during the monsoon. ${ }^{10} \mathrm{I}$ created total nominal assets held by the family by summing across household stocks, farm implements, farm buildings, and farm livestock, and financial assets and liabilities. I deflated nominal assets by the village-level CPI to create real assets.

\section{Empirical Results}

\section{IV.1 Empirical Analysis of Wages}

The model presented here argues that the village-level wage in the second-period responds to the rainfall shock, in a way which may depend on the extent to which the local labor force is affected by industrialization. If this model is correct, there is an unanticipated "surprise" in the second-period wage which the farmer cannot forecast at the beginning of the crop cycle. This wage surprise should be correlated with the village-level weather shock. Unfortunately, the ICRISAT data have only limited information available on the extent of non-agricultural employment in the study villages.

I first examined the wage response to rainfall variables using the wage paid to male laborers. In order to estimate the surprise in the wage structure, I regressed the second-period wage against the first-period wage using village-level fixed effects. I took the residual from

\footnotetext{
${ }^{10}$ I am grateful to Mark Rosenzweig for making these data available.
} 
that model as the measure of the surprise in wages, e.g. the unanticipated movement in wages in the second period which the farmer could not have forecast at the beginning of the first period. This assumes that the farmer can use the first-period wage, but no other information, to forecast the second period wage. ${ }^{11}$ This is a less-than-perfect estimate of the true response of wages to the weather shock since it may not include all the information the farmer has available to forecast second-period wages. The farmer himself has knowledge of a number of other factors which may affect the response of wages to the shock, including information on the local labor market at the beginning of the crop cycle. The farmer also has years of experience with the local labor market which offer insight in to how the market is likely to respond to the weather shock. ${ }^{12}$

Using only the information on the weather shock and not controlling for the effect of mitigating factors, I found the following relationship:

$$
\begin{aligned}
& \text { SHOCK }=.0029-.00177 * \text { ONSET } \text {. } \\
& \text { (0.248) (-2.186) }
\end{aligned}
$$

where SHOCK measures the shock to the second-period male wage as defined above and

\footnotetext{
${ }^{11}$ A more extensive analysis would include all factors that might affect the farmer's forecast of the second period wage. For example, the extent of modernization of traditional agriculture might affect the response of the second period wage. Use of chemical fertilizer (and highyielding varieties of seeds) will increase the effect of a positive production shock since crop output will respond even more to the weather shock. I consider the effect of fertilizer use below.

${ }^{12}$ For example, the specification here fails to take account of the fact that the local labor market may be in disequilibrium. If the farmer knew that the local labor market was in disequilibrium, e.g. there was excess supply of labor which had not been absorbed in the market, he would know that the effects of the shock were likely to be slight.
} 
ONSET measures the deviation of the monsoon onset date from its mean ${ }^{13}$ Standard $t$ statistics based on 50 observations are given in parentheses. The ONSET variable is statistically significant at a two and one-half percent confidence level (using a one-tailed test), e.g. a delay in the onset of the monsoon increases the random component of the second period wage, ceteris paribus. The R-squared in the regression was only .09, indicating that the monsoon onset explained somewhat less than ten percent of the shock to second period wages.

Any factor which is known to the farmer in the first period may be useful in forecasting the second period wage, and if farmers make efficient forecasts they will use all available information. Since the paper argues that there is an important interaction between fertilizer use in the first period and wages, we might expect an important interaction between fertilizer prices and the second period wage. I attempted to test the importance of fertilizer prices in determining the second period wage. I regressed the second period male wage against the first period male wage and the real price of fertilizer in the village. I then used the residual from this regression as the dependent variable in the second regression, e.g. as a measure of the shock to wages in the second period.

If the model is a reasonable description of reality, we would expect fertilizer prices to tell us something about second period wages. In fact, the coefficient on the real price of fertilizer in the first stage regression had a p-value of only .06 , indicating that it was only marginally significant. In the second stage regression, however, I found that none of the rainfall measures were statistically significant in explaining the wage shock by themselves.

\footnotetext{
${ }^{13} \mathrm{~A}$ positive deviation in the monsoon onset date means that the onset has been delayed, e.g. it corresponds to a negative weather shock in the theoretical model.
} 
However, in a regression of the shock against all four rainfall measures, two of the four coefficients were statistically significant at the five percent level, and one was significant at the 10 percent level. Oddly enough, the monsoon onset date is no longer statistically significant. The regression is reported in equation (8):

$$
\begin{aligned}
& \text { SHOCK }=0.000161-0.00034 * \text { ONSET }-0.00021 * \text { TOT }+0.3322 * \text { FDAY }+0.0011 * \text { END }(8) \\
& \begin{array}{llll}
(0.013) \quad(-0.381) & (-2.315) \quad(1.836)
\end{array}
\end{aligned}
$$

The R-squared in this regression was 0.19 , indicating that the set of rainfall variables together explained almost 20 percent of the surprise in second-period wages, where the surprise was calculated conditional on the real price of fertilizer.

The model above predicts that the response of the wage to the shock will be lower when there is non-agricultural employment available to farmers in the village. The demand for labor from outside the agricultural sector breaks the link between the weather shock and the wage. Three of the ten ICRISAT villages villages reported participation in government sponsored work programs: Shirapur, Kanzara, and Rampura Kalan. The government work program softens the effect of a negative surprise in wages on the local labor market.

To test for the effect of government employment on the response of wages to the rainfall shock, I augmented the above regressions. I created a dummy variable to control for presence of government employment, and then interacted the dummy variable with each of the four variables that measure the weather shock to determine the effects of the government scheme on the surprise in male wages. Results of regressions of the wage surprise against various measures of the rainfall shock are reported in table 2. I first calculated the wage shock as the residual from a regression of second period wages against only the first period wage. For male wages (column 1), I found that the total rainfall during the monsoon and the 
frequency of days with rainfall were both statistically significant when interacted with the dummy for the presence of a government work program. None of the direct measures of the rainfall variable were statistically significant and an F-test for the joint significance of all the direct rainfall variables did not reject the null hypothesis of no relationship. The F-test for the joint significance of the terms measuring the interaction of second period wages and the presence of a government work scheme did reject the null hypothesis of no relationship at the IO percent level. For female wages (column 3), I did not find a statistically significant relationship for any of the variables. Moreover F-tests for joint significance did not reject the null hypothesis at the five percent level.

As before, I also calculated the surprise in wages as the residual from a regression of second period wages against first period wages and the real price of fertilizer. Regressions of these shock measures against the rainfall variables, and their interactions with government work programs are reported in columns (2) and (4). The effect of various measures of rainfall on these wage "shocks" is similar to the previous definition of the shock for male wages (column 2). Now the monsoon onset is not statistically significant when interacted with the dummy for works programs, but the F-test for joint significance of all interaction variables has a lower p-value associated with it. However, for female wages, coefficients on two of the rainfall variables interacted with the dummy for a government work program are now statistically significant at the one percent level in these regressions. MOreover, an F-test rejects the null hypothesis of no relationship between the government programs and the wage shock at less than the five percent significance level. Moreover, the sign on the coefficients on the interaction terms are always opposite to the signs of the coefficients on the direct 
rainfall measures, indicating that the government program cushions the response of secondperiod wages to weather shocks.

\section{IV.2 Fertilizer Demand}

To estimate fertilizer demand, I considered a linear approximation to the decision rule implied in equation (6). The linear approximation can be thought of as first-order approximation to the true demand equation, which depends on assumptions about the utility function, including the degree of risk-aversion. Letting " $i$ " index individuals and " $t$ " index time, fertilizer demand may be written as ${ }^{14}$ :

$$
\mathrm{X}_{\mathrm{it}}^{*}=\beta_{0 \mathrm{i}}+\mathrm{Z}_{\mathrm{t}}^{1} \beta+\epsilon_{\mathrm{it}}
$$

Complications arise from two characteristics of the data. First, for some households, no fertilizer will be used in production, or no labor will be supplied off-farm or, which gives rise to the censoring model first discussed by Tobin (1956). Equation (9) allows the intercept term in each equation to vary between households in the sample, but to be constant for a given household over time. ${ }^{15}$ If the intercept term is treated as a non-stochastic parameter to be estimated for each household, the model generates fixed-effects or "within" estimates, e.g. only the variation within a household is used in determining the relationship between variables.

To account for both the censoring in the dependent variable and the panel nature of the data, I use a fixed-effects Tobit estimator to estimate both fertilizer demand and off-farm

\footnotetext{
${ }^{14}$ While these equations form part of a system of derived demand and supply equations arising from the optimization model, I ignore the cross-equation relationships between the dependent variables in the present study.

${ }^{15}$ This is consistent with the fact that there is no role in the model for learning.
} 
labor supply. ${ }^{16}$ However, including a dummy variable to account for each household and then using standard Tobit estimation yields results which are unbiased, but not consistent as the number of individuals increases and the number of time periods is constant. The inconsistency arises because as the number of individuals increases, the number of coefficients to estimate increases at the same rate. Honore (1992) proposes trimmed least-absolute deviation (LAD) and trimmed least-squares (LS) estimators which do not make distributional assumptions on the error terms in the equations. Honore shows that the difference between $X_{i, t}$ and $X_{i, t+1}-X_{i, t+1} X_{i, t}-$ is distributed symmetrically around the true regression line even if $\mathrm{X}_{\mathrm{i}, \mathrm{t}}$ and $\mathrm{X}_{\mathrm{i}, \mathrm{t}+1}$ are censored. Taking the absolute value of the "trimmed" deviations yields Honore's trimmed LAD estimator, and squaring the deviations yields the trimmed LS estimator. Honore shows that the trimmed estimators are consistent and asymptotically normal when the underlying model is accurately described by fixed effects. Since they do not estimate the fixed effects directly, they are consistent as the number of individuals goes to infinity and the number of time periods is fixed. This approach is ideally suited for the case of short panels, such as the ICRISAT data.

Estimates of the fertilizer demand equation using Honore's fixed-effects Tobit estimator are reported in Table 3. The dependent variable is fertilizer use per acre of total cropped area. I first estimated the demand equation using first period wages, the real price of fertilizer, share of irrigated land, total cropped area, real assets, and the standard deviation of

\footnotetext{
${ }^{16}$ Failure to control for fixed effects will bias estimates if there are included variables which are correlated with the omitted fixed-effect terms. This may be important in explaining the coefficient estimates for total area farmed, which I report below.
} 
various measures of the village-level weather shock interacted with assets. ${ }^{17}$ The coefficient on the real price of fertilizer was not statistically significant. Both first-period male and female wages were statistically significant at the one percent level, but the coefficients were of opposite signs. The coefficient estimates indicated that fertilizer and first-period female labor were complements but fertilizer and male labor were substitutes in production. A higher share of irrigated land increased fertilizer use, and farmers who cropped a larger area used less fertilizer per acre than smaller farmers. The negative relationship between area and fertilizer use is consistent with the inverse productivity relationship, which says that smaller farmers tend to farm more intensively. Neither total assets nor household assets were statistically significant in the regressions at any reasonable significance level.

I tested for the joint statistical significance of coefficients on various measures of the spread in the distribution of the rainfall shock interacted with household assets, but I could not reject a null hypothesis that the variability of rainfall had no effect on fertilizer use, using chi-squared tests. These generally support the theoretical result that fertilizer demand does not necessarily decrease with increases in risk, measured as variability of the random production shock.

I also estimated the fertilizer demand equation including controls for second-period wages. While the second-period wages are not known at the time fertilizer decisions are made, second-period wages are not uncorrelated with first-period wages. To the extent that farmers' forecasts of second-period wages effects their decision to use fertilizer, omitting them from the regression biases coefficient estimates. The only coefficient estimates which are

\footnotetext{
${ }^{17}$ Fixed-effects estimation precludes use of the standard deviation in the regressions.
} 
changed substantially by including the second-period wages are the estimates of first-period wage coefficients. When I control for second-period wages, first-period male labor and fertilizer are now complements. The estimated coefficients on second-period wages for both male and female labor are positive, indicating that second-period labor and fertilizer use are substitutes.

\section{IV.3 Off-farm Labor Supply}

One important theoretical results of the model above is that farmers use off-farm labor supply in the second period to mitigate the effects of production shocks, and that those shocks are likely to be more important when farmers use chemical fertilizers. Fertilizer use represents an important production decision for farmers in India's semi-arid tropics, since it is an important purchased input and a source of increased output and increased risk. Accounting for fertilizer use, the weather shock has both a direct and indirect effect. While a positive (negative) shock raises (lowers) the marginal product of on-farm labor, it raises (lowers) the marginal productivity of production labor more when a farmer uses chemical fertilizers. Moreover, since the fertilizer is a purchased input, a negative production shock has an income effect related to the household's expenditure on fertilizer.

I estimated the second-period labor supply equation for male and female labor separately. Separate estimation by gender is justified, since labor markets in the study villages are largely segregated by sex. ${ }^{18}$ I used Honore's fixed-effects Tobit estimator to provide consistent estimates in the presence of fixed effects across time. I consider two

\footnotetext{
${ }^{18}$ Women are prevented from touching the plow by taboo, and men do not perform domestic chores by custom (Walker and Ryan, 1990, p. 110).
} 
separate formulations of the model: If markets are perfect, then the effect of first-period variables on second-period decisions, such as labor supply, will be fully captured by the inclusion of prices (and wages) from the first-period in the labor supply equation for the second period. However, if markets are imperfect, then farmers may not be able to adjust their production plans to the first-period prices, and they may not accurately measure the effect of first-period decisions on second-period variables. Supervision costs, which raise the effective marginal product of family labor, also make market prices less indicative of real costs of the input. In that case, I can better estimate the effects of first-period choices on second-period variables by including the quantity of the first-period variable directly. If production decisions are made sequentially, there is no endogeneity problem. The estimated parameters of the fertilizer demand equation discussed above suggest that the market for fertilizer may not clear in the ICRISAT study villages. I therefore focus on estimates conditional on the quantity of first-period labor supplied off farm and fertilizer intensity (table 4). Off-farm labor supply equations conditional on first-period prices are reported in table 5 .

Columns (1) and (3) of table 4 report estimates of labor supply conditional on the quantity of fertilizer used and the quantity of male and female off-farm labor supply in the first-period. I also controlled for total area cropped, the share of irrigated land, household assets and various measures of the weather shock (including interactions) measured as the deviations from mean in four rainfall variables. The quantity of fertilizer used is statistically significant in both male and female labor supply equations. However, the empirical results indicate that fertilizer use affects supply of male and female labor quite differently. Second- 
period male (production) labor and fertilizer use appear to be complements: An increase in fertilizer use reduces off-farm labor supply, as we would expect if $f_{x l}>0$. On the other hand, there is a positive correlation between fertilizer use and second-period female labor supplied off-farm. Both male and female labor were characterized by a backward-bending labor supply curve, and for both males and females, second-period labor and first-period labor were complements. I found that households with relatively greater cropped area tended to supply less male labor to the off-farm market, but that there was no significant relationship between female labor supplied off-farm and the total area farmed. In a static decision-making model, if agents are risk averse, and have declining relative risk aversion, then wealthier households will be less likely to over-supply labor to the wage labor market. The coefficient on real assets was not statistically significant. To the extent that real assets affect secondperiod labor supply only through first-period choices, and I explicitly control for first-period variables in these regressions, it is not surprising that the coefficient was not significant. The share of irrigated land was not statistically significant, even when interacted with various rainfall measures. A chi-squared test for the joint statistical significance of the direct weather shock variables rejected a null-hypothesis of no significance at the 10 percent level. The more striking set of relationships is the interaction between fertilizer use and the various measures of the rainfall shock. For male labor supplied off-farm, few of the interaction terms were statistically significant by when included directly in the regression. However, I rejected the null hypothesis that all the fertilizer variables were not significant at less than the one percent level. For female labor supply, coefficients on each of the interaction terms was statistically significant at less than the one percent significance level. These results indicate 
that female labor supplied off-farm is highly sensitive to the production shocks affecting farm output.

Columns (1) and (3) of Table 5 contain coefficient estimates (t-statistics are in parentheses) and the results of some chi-squared tests. For both male and female labor supply increases in the price of fertilizer raise off-farm labor supply in the second period indicating that production labor and fertilizer are complements $\left(\mathrm{f}_{\mathrm{xl}}>\mathrm{O}\right)$. Both male and female labor have backward bending supply curves. The wage effects are conditional on the weather shock, e.g. they measure the response to wages for a given realization of the weather shock. ${ }^{19}$ The comparative static results predict that the response of (off-farm) labor supply in the second period to weather shocks depends crucially on first-period choices, and that the response will be stronger the greater is fertilizer use. For both male and female labor supply the empirical results support the theoretical result: off-farm labor supply responds to the weather shock primarily through its interaction with first-period choices. There is no statistically significant direct relationship between the rainfall shock and off-farm labor supply, exclusive of interactions with fertilizer use: Chi-squared test for the joint significance of the 4 rainfall variables failed to reject the null hypothesis at the five percent level. Chisquared tests for the joint significance of all fertilizer variables--those measuring the direct effect and those measuring the interaction of fertilizer variables and the shock variable--reject the null hypothesis at less than a 1 percent significance level.

The comparative static results derived in the appendix indicate the response of the

\footnotetext{
${ }^{19}$ I also included several terms which measure the interaction of rainfall with other variables, e.g. fertilizer use and irrigation.
} 
second-period labor supply is different for negative and positive shocks. To test whether this pattern was confirmed in the data, I constructed one-sided shock variables corresponding to a negative production shock. Increases in the monsoon onset date are a negative production shock, so I created one-sided shock variables that are equal to the shock when the shock is greater than zero, and zero otherwise. An earlier monsoon end date, however, indicates a shorter monsoon, and was treated as a negative shock, so I created a variable that it is equal to the deviation of the monsoon end date from the average end date when this is less than zero, and zero else. Similar "one-sided" variables were created for the frequency of days with rainfall, and total rainfall during the monsoon. ${ }^{20}$

Estimates when I include the one-sided shocks and condition on the quantity of fertilizer used and first-period off-farm labor supply are reported in columns (2) and (4) of Table 4. For female labor supply, the one-sided weather shocks are highly statistically significant: the chi-squared statistic for joint significance has a p-value less than 1 percent. For male labor supply, the one-sided shocks are not statistically significant at even the ten percent level. The general pattern of coefficient estimates for other variables is not much different from estimates in which I did not use one-sided variables in the regressions. However, for regressions when I condition on one-sided shocks, the coefficient on fertilizer intensity is no longer statistically significant at any reasonable level. These results indicate that female labor supply responds much more acutely to negative production shocks than does male labor supply. Results using the one-sided shock variables, and conditioning on the first-

20 The choice of which half of the variable to control for is arbitrary. Since I include the full rainfall shock variable in the regression as well, the other side of the shock variable is controlled for. 
period prices, are shown in columns (2) and (4) of Table 5. Most coefficient estimates are generally similar to the previous case. The chi-squared test statistic for joint significance of the one-sided shocks has a p-value of 0.2 percent for the equation explaining female labor supply, but is not significant at the five percent level in the male labor supply equation.

It is useful to compare these coefficients to those estimated for fertilizer demand. In the fertilizer demand estimates (table 3), I found that first-period female labor and fertilizer use were complements, and second-period female labor and fertilizer were substitutes. In the labor supply equations, fertilizer and second-period female labor were also substitutes. The relationship between fertilizer use and male labor was statistically weak. However, in labor supply eqautions, fertilizer variables were highly statistical significant. While size and irrigation were statistically significant in explaining fertilizer demand, they played only a minimal role in explaining labor supply. Assets were not important in either the fertilizer regressions or the labor-supply equations.

\section{Conclusion}

I develop a two-period stochastic dynamic programming model to describe the effect of off-farm labor on fertilizer use by a risk averse, utility maximizing farmer. I find that in the model the farmer supplies less labor off-farm the more fertilizer he uses and that increases in the share of irrigable land should decrease off-farm labor supply and increase the use of chemical fertilizers. I use a well-known data set on a sample of farmers in the semi-arid tropics of India to test the model. I find that the farmers use more fertilizer the greater is their share of irrigated land and that larger farmers use fertilizer less intensively. More importantly, fertilizer use responds to both male and female wages, although the response is 
stronger to female wages. Empirical results on post-monsoon labor supply show that there are important interactions between fertilizer use and the effect ofthe weather shocks on off-farm labor supply. The direct effects of the weather variables are only marginally statistically significant. I found that female labor supply was much more sensitive to the surprise in weather variables than was male supply.

These results imply that programs designed to promote the use of modern inputs such as fertilizer -- which raise average yields but increase risk as well -- should consider carefully the interactions between production decisions and participation in the labor market. The impact of negative production shocks on women in developing countries should be carefully considered when promoting modernization of traditional agriculture. In addition, the role of the labor market in smoothing consumption in the face of production shocks should be noted. A well-designed government work scheme could take the place of a lending program to mitigate the effects of negative production shocks. Programs which make the second-period wage less responsive to shocks should raise fertilizer use. 
Table 1

Variable Names Used in ICRISAT Models

RW_M_1 Real wage for males, first period

RW_M_2 Real wage for males, second period

RW_F_1 Real wage for females, first period

RW_F_2 Real wage for females, second period

Q_M_1 Labor supply by males, first period

Q_F_1 Labor supply by females, first period

SHRE_IRRI Share of crop area served by irrigation

AREA Total area in crops for a given year

DEV_ON Deviation in monsoon onset date

DEV_END Deviation in monsoon end date

DEV_FDAY Deviation in the frequency of days with rain

DEV_TOT Deviation in total rainfall

POS_ON DEV_ON if DEV_ON $>\mathrm{O}$; O else

NEG_END DEV_END if DEV_END $<\mathrm{O}$; O else

POS_FDAY DEV_FDAY if DEV_FDAY $>\mathrm{O}$; O else

POS_TOT DEV_TOT if DEV_TOT $>0$; O else 
Table 2

Response of second-period wages to weather and government Programs

Dependent Variable: Residual from wage regressions

\begin{tabular}{|c|c|c|c|c|}
\hline & & & & \\
\hline & (1) & (2) & (3) & (4) \\
\hline Constant & $\begin{array}{c}0.00 \\
(0.02)\end{array}$ & $\begin{array}{l}-0.003 \\
(-0.175)\end{array}$ & $\begin{array}{c}-0.003 \\
(-0.207)\end{array}$ & $\begin{array}{l}-0.002 \\
(-0.115)\end{array}$ \\
\hline $\begin{array}{l}\text { Deviation in monsoon } \\
\text { onset date }\end{array}$ & $\begin{array}{r}-0.001 \\
(-1.07)\end{array}$ & $\begin{array}{l}-0.001 \\
(-0.557))\end{array}$ & $\begin{array}{c}0.000 \\
(0.296)\end{array}$ & $\begin{array}{l}-0.000 \\
(-0.342)\end{array}$ \\
\hline $\begin{array}{l}\text { Deviation in monsoon } \\
\text { end date }\end{array}$ & $\begin{array}{c}0.001 \\
(0.724)\end{array}$ & $\begin{array}{c}0.001 \\
(1.099)\end{array}$ & $\begin{array}{c}0.001 \\
(1.051)\end{array}$ & $\begin{array}{c}0.000 \\
(0.357)\end{array}$ \\
\hline $\begin{array}{l}\text { Deviation in total } \\
\text { monsoon rainfall }\end{array}$ & $\begin{array}{c}0.000 \\
(0.661)\end{array}$ & $\begin{array}{c}0.000 \\
(0.074)\end{array}$ & $\begin{array}{l}-0.000 \\
(-0.595)\end{array}$ & $\begin{array}{c}0.000 \\
(0.893)\end{array}$ \\
\hline $\begin{array}{l}\text { Deviation in frequency } \\
\text { of rainfall days }\end{array}$ & $\begin{array}{c}-0.128 \\
(-0.647)\end{array}$ & $\begin{array}{c}-0.036 \\
(-0.162)\end{array}$ & $\begin{array}{c}0.060 \\
(0.349)\end{array}$ & $\begin{array}{l}-0.155 \\
(-0.864)\end{array}$ \\
\hline $\begin{array}{l}\text { Dummy, government } \\
\text { works programs }\end{array}$ & $\begin{array}{c}0.003 \\
(0.144)\end{array}$ & $\begin{array}{c}0.012 \\
(0.499)\end{array}$ & $\begin{array}{l}0.005 \\
(0.243)\end{array}$ & $\begin{array}{c}0.010 \\
(0.535)\end{array}$ \\
\hline $\begin{array}{l}\text { Government dummy * } \\
\text { monsoon onset date }\end{array}$ & $\begin{array}{c}-0.003 \\
(-1.806)\end{array}$ & $\begin{array}{c}-0.001 \\
(-0.284)\end{array}$ & $\begin{array}{c}-0.001 \\
(-0.620)\end{array}$ & $\begin{array}{c}0.001 \\
(0.804)\end{array}$ \\
\hline $\begin{array}{l}\text { Government dummy * } \\
\text { monsoon end date }\end{array}$ & $\begin{array}{c}0.000 \\
(0.651)\end{array}$ & $\begin{array}{c}0.001 \\
(0.808)\end{array}$ & $\begin{array}{c}-0.002 \\
(-0.230)\end{array}$ & $\begin{array}{c}0.001 \\
(0.904)\end{array}$ \\
\hline $\begin{array}{l}\text { Government dummy } * \\
\text { total monsoon rainfall }\end{array}$ & $\begin{array}{l}-0.00 \\
(-2.144)\end{array}$ & $\begin{array}{c}-0.000 \\
(-2.813)\end{array}$ & $\begin{array}{c}0.000 \\
(0.064)\end{array}$ & $\begin{array}{l}-0.000 \\
(-2.920)\end{array}$ \\
\hline $\begin{array}{l}\text { Government dummy } * \\
\text { frequency of rain days }\end{array}$ & $\begin{array}{c}0.717 \\
(2.144)\end{array}$ & $\begin{array}{l}0.917 \\
(2.553)\end{array}$ & $\begin{array}{c}0.292 \\
(0.973)\end{array}$ & $\begin{array}{c}0.901 \\
(3.103)\end{array}$ \\
\hline $\begin{array}{l}\text { F-test for significance of } \\
\text { all rainfall variables }\end{array}$ & $\begin{array}{l}0.64 \\
(0.63)^{2}\end{array}$ & $\begin{array}{c}0.51 \\
(0.73)\end{array}$ & $\begin{array}{c}0.30 \\
(0.88)\end{array}$ & $\begin{array}{c}0.40 \\
(0.81)\end{array}$ \\
\hline $\begin{array}{l}\text { F-test for significance } \\
\text { of interaction terms }\end{array}$ & $\begin{array}{c}2.30 \\
(0.08)\end{array}$ & $\begin{array}{l}2.60 \\
(0.05)\end{array}$ & $\begin{array}{c}0.57 \\
(0.69)\end{array}$ & $\begin{array}{l}2.76 \\
(0.04)\end{array}$ \\
\hline
\end{tabular}

${ }^{21}$ Numbers in parentheses for F-tests are p-values for two-sided significance tests. 
Table 3

\section{Fixed-effects Tobit Estimates for Fertilizer Demand}

Dependent Variable: Fertilizer use per Acre $^{22}$

Real fertilizer price

0.30

0.92

$(0.07)$

$(0.19)$

Real wage, female, period 1

$-81.2$

$-149.1$

$(-2.45)$

$(-3.16)$

Real wage, male, period 1

52.2

$-36.1$

$(3.05)$

Real wage, female, period 2

139.9

Real wage, male, period 2

35.7

(1.28)

Total area

$-0.49$

$-0.56$

$(-2.67)$

$(-2.68)$

Share of irrigated land

26.7

26.3

(2.49)

(2.21)

Real assets

0.00

0.00

(0.09)

$(0.03)$

Real assets in

$-0.00$

$-0.00$

household stocks

$(-0.20)$

$(-0.22)$

Std. Dev. in monsoon

$-0.00$

0.00

onset * real assets

$(-0.31)$

(0.11)

Std. Dev. in total rainfall*

$-0.00$

$-0.00$

real assets

$(-0.06)$

$(-0.05)$

Std. Dev. in frequency

0.00

$-0.00$

of raindays * real assets

(0.01)

$(-0.00)$

\footnotetext{
${ }^{22} \mathrm{t}$-statistics are shown in parentheses.
} 
Chi-squared test for joint significance of assets

Chi-squared test for joint significance of std.dev.
0.0

$(p$-value $=97.7 \%)$

0.4

$(\mathrm{p}$-value $=93.8 \%)$
0.0

$(p$-value $=97.5 \%)$

0.1

$(p-$ value $=98.9 \%)$ 
Table 4

Fixed Effects Estimates for Off-Farm Labor Supply With Controls for First-period Quantities

\begin{tabular}{|c|c|c|c|c|}
\hline & & & & \\
\hline & (1) & (2) & (3) & (4) \\
\hline Fertilizer intensity & $\begin{array}{l}-0.17 \\
(-4.17)\end{array}$ & $\begin{array}{c}-0.18 \\
(-0.50)\end{array}$ & $\begin{array}{c}0.15 \\
(3.59)\end{array}$ & $\begin{array}{c}-0.07 \\
(-0.30)\end{array}$ \\
\hline $\begin{array}{l}\text { Quantity of female labor, } \\
\text { period } 1\end{array}$ & $* * *$ & $* * *$ & $\begin{array}{c}0.54 \\
(3.52)\end{array}$ & $\begin{array}{c}0.50 \\
(4.09)\end{array}$ \\
\hline Real wage, female, period 2 & $* * *$ & $* * *$ & $\begin{array}{l}-10.8 \\
(-3.86)\end{array}$ & $\begin{array}{c}-11.5 \\
(-3.49)\end{array}$ \\
\hline $\begin{array}{l}\text { Quantity of male labor, } \\
\text { period } 1\end{array}$ & $\begin{array}{c}0.58 \\
(2.02)\end{array}$ & $\begin{array}{c}0.56 \\
(1.77)\end{array}$ & $* * *$ & $* * *$ \\
\hline Real wage, male, period 2 & $\begin{array}{l}-19.9 \\
(-3.32)\end{array}$ & $\begin{array}{l}-28.19 \\
(-3.29)\end{array}$ & $* * *$ & $* * *$ \\
\hline Total area farmed & $\begin{array}{l}-0.13 \\
(-2.24)\end{array}$ & $\begin{array}{c}-0.17 \\
(-1.89)\end{array}$ & $\begin{array}{c}0.04 \\
(0.98)\end{array}$ & $\begin{array}{c}0.05 \\
(1.06)\end{array}$ \\
\hline Share of irrigated land & $\begin{array}{c}-0.93 \\
(-0.25)\end{array}$ & $\begin{array}{c}-4.86 \\
(-0.84)\end{array}$ & $\begin{array}{l}-0.16 \\
(-0.06)\end{array}$ & $\begin{array}{c}0.54 \\
(0.29)\end{array}$ \\
\hline $\begin{array}{l}\text { Monsoon onset * } \\
\text { Share of irrigated land }\end{array}$ & $\begin{array}{c}0.06 \\
(0.22)\end{array}$ & $\begin{array}{c}0.28 \\
(0.69)\end{array}$ & $\begin{array}{c}-0.04 \\
(-0.10)\end{array}$ & $\begin{array}{c}-0.04 \\
(-0.08)\end{array}$ \\
\hline $\begin{array}{l}\text { Frequency of rainfall days } \\
\text { Share of irrigated land }\end{array}$ & $\begin{array}{c}-1.77 \\
(-0.03)\end{array}$ & $\begin{array}{c}9.10 \\
(0.13)\end{array}$ & $\begin{array}{l}30.85 \\
(1.27)\end{array}$ & $\begin{array}{r}23.87 \\
(0.87)\end{array}$ \\
\hline Real assets & $\begin{array}{c}-0.00 \\
(-0.34)\end{array}$ & $\begin{array}{c}-0.00 \\
(-0.13)\end{array}$ & $\begin{array}{l}-0.00 \\
(-1.41)\end{array}$ & $\begin{array}{c}-0.00 \\
(-1.14)\end{array}$ \\
\hline Monsoon onset & $\begin{array}{c}0.01 \\
(0.11)\end{array}$ & $\begin{array}{l}0.15 \\
(0.52)\end{array}$ & $\begin{array}{c}-0.01 \\
(-0.37)\end{array}$ & $\begin{array}{c}0.11 \\
(1.50)\end{array}$ \\
\hline Monsoon end & $\begin{array}{c}0.03 \\
(0.82)\end{array}$ & $\begin{array}{r}-0.26 \\
-1.42)\end{array}$ & $\begin{array}{c}0.03 \\
(2.59)\end{array}$ & $\begin{array}{c}-0.02 \\
(-0.56)\end{array}$ \\
\hline Frequency of rainfall days & $\begin{array}{c}-6.54 \\
(-0.47)\end{array}$ & $\begin{array}{l}-43.18 \\
(-1.47)\end{array}$ & $\begin{array}{c}0.39 \\
(0.11)\end{array}$ & $\begin{array}{l}-9.67 \\
(-1.57)\end{array}$ \\
\hline Total rainfall & $\begin{array}{c}-0.01 \\
(-1.70)\end{array}$ & $\begin{array}{c}-0.04 \\
(-1.49)\end{array}$ & $\begin{array}{l}-0.00 \\
(-0.26)\end{array}$ & $\begin{array}{c}0.00 \\
(0.28)\end{array}$ \\
\hline $\begin{array}{l}\text { Monsoon onset } * \\
\text { fertilizer intensity }\end{array}$ & $\begin{array}{l}-11.2 \\
(-1.01)\end{array}$ & $\begin{array}{l}-22.9 \\
(-0.62)\end{array}$ & $\begin{array}{l}30.3 \\
(6.39)\end{array}$ & $\begin{array}{c}5.26 \\
(0.24)\end{array}$ \\
\hline $\begin{array}{l}\text { Monsoon end } * \\
\text { fertilizer intensity }\end{array}$ & $\begin{array}{c}1.68 \\
(0.53)\end{array}$ & $\begin{array}{c}-5.47 \\
(-1.46)\end{array}$ & $\begin{array}{c}-0.01 \\
(-3.93)\end{array}$ & $\begin{array}{l}-0.00 \\
(-2.89)\end{array}$ \\
\hline $\begin{array}{l}\text { Frequency of rainfall days * } \\
\text { fertilizer intensity }\end{array}$ & $\begin{array}{r}2335 \\
(2.36)\end{array}$ & $\begin{array}{r}2795 \\
(1.95)\end{array}$ & $\begin{array}{r}-2699 \\
(-4.78)\end{array}$ & $\begin{array}{r}-2303 \\
(-2.79)\end{array}$ \\
\hline $\begin{array}{l}\text { Total rainfall * } \\
\text { fertilizer intensity }\end{array}$ & $\begin{array}{l}-0.09 \\
(-0.43)\end{array}$ & $\begin{array}{l}-0.742 \\
(-0.87)\end{array}$ & $\begin{array}{c}0.00 \\
(5.00)\end{array}$ & $\begin{array}{c}0.00 \\
(2.69)\end{array}$ \\
\hline
\end{tabular}




\begin{tabular}{|c|c|c|c|c|}
\hline Positive monsoon onset & $* * *$ & $\begin{array}{l}-0.75 \\
(-2.37)\end{array}$ & $* * *$ & $\begin{array}{c}-0.48 \\
(-3.40)\end{array}$ \\
\hline Negative monsoon end & $* * *$ & $\begin{array}{r}0.56 \\
(1.70)\end{array}$ & $* * *$ & $\begin{array}{c}0.07 \\
(1.02)\end{array}$ \\
\hline Positive total rainfall & $* * *$ & $\begin{array}{c}0.03 \\
(1.10)\end{array}$ & $* * *$ & $\begin{array}{c}-0.00 \\
(-0.37)\end{array}$ \\
\hline $\begin{array}{l}\text { Positive frequency of } \\
\text { rainfall days }\end{array}$ & $* * *$ & $\begin{array}{c}70.8 \\
(1.85)\end{array}$ & $* * *$ & $\begin{array}{l}19.96 \\
(1.75)\end{array}$ \\
\hline $\begin{array}{l}\text { Positive onset } * \\
\text { fertilizer intensity }\end{array}$ & $* * *$ & $\begin{array}{c}-0.00 \\
(-0.05)\end{array}$ & $* * *$ & $\begin{array}{c}0.07 \\
(1.18)\end{array}$ \\
\hline $\begin{array}{l}\text { Chi-squared test for } \\
\text { fertilizer variables }\end{array}$ & $\begin{array}{c}21.4 \\
\text { (p-value }=0.0 \%)\end{array}$ & $\begin{array}{c}13.4 \\
\text { (p-value }=3.70 \%)\end{array}$ & $\begin{array}{c}195.8 \\
\text { (p-value }=0.00 \%)\end{array}$ & $\begin{array}{c}133.5 \\
\text { (p-value }=0.00 \%)\end{array}$ \\
\hline $\begin{array}{l}\text { Chi-squared test for } \\
\text { rainfall shock }\end{array}$ & $\begin{array}{c}7.9 \\
\text { (p-value }=9.6 \%)\end{array}$ & $\begin{array}{c}5.7 \\
\text { (p-value }=22.3 \%)\end{array}$ & $\begin{array}{c}8.0 \\
\text { (p-value }=9.0 \%)\end{array}$ & $\begin{array}{c}7.9 \\
\text { (p-value }=9.30 \%)\end{array}$ \\
\hline $\begin{array}{l}\text { Chi-squared test for } \\
\text { irrigation variables }\end{array}$ & $\begin{array}{c}0.3 \\
\text { (p-value }=95.8 \%)\end{array}$ & $\begin{array}{c}0.2 \\
\text { (p-value }=97.2 \%)\end{array}$ & $\begin{array}{c}4.0 \\
\text { (p-value }=26.3 \%)\end{array}$ & $\begin{array}{c}4.9 \\
(p-v a l u e=18.4 \%)\end{array}$ \\
\hline $\begin{array}{l}\text { Chi-squared test for } \\
\text { one-sided shocks }\end{array}$ & $* * *$ & $\begin{array}{c}8.0 \\
(p \text {-value }=15.6 \%)\end{array}$ & $* * *$ & $\begin{array}{c}22.0 \\
\text { (p-value }=0.00 \%)\end{array}$ \\
\hline
\end{tabular}


Table 5

Fixed Effects Estimates for Off-Farm Labor Supply With Controls for First-period Prices

MALE

(2)

FEMALE

Real fertilizer price

Real wage, female, period 1

Real wage, female, period 2

Real wage, male, period 1

Real wage, male, period 2

Total area farmed

Share of irrigated land

Monsoon onset *

share of irrigated land

Frequency of rainfall days * share of irrigated land

Real assets

Monsoon onset

Monsoon end

Frequency of rainfall days

Total rainfall

Monsoon onset*

real fertilizer price

Monsoon end *

real fertilizer price

Frequency of rainfall days * real fertilizer price
11.24

(4.04)*

$* * *$

***

$-0.05$

$(-0.00)$

$-12.0$

$(-1.98)$

$-0.13$

$(-2.19)$

$-1.34$

$(-0.31)$

$-0.12$

$(-0.29)$

12.9

(0.14)

$-0.00$

$(-0.41)$

$-0.15$

$(-0.28)$

$-0.12$

$(-0.43)$

$-65.7$

$(-0.95)$

0.003

(0.08)

28.2

(0.12)

78.6

(0.56)

3033

(0.87)
11.2

(3.39)

$* * *$

***

$-4.97$

$(-0.50)$

$-21.1$

$(-1.88)$

$-0.17$

$(-2.07)$

$-6.40$

$(-1.04)$

$-0.06$

$(-0.14)$

43.9

(0.47)

$-0.00$

$(-0.05)$

$-0.14$

$(-0.18)$

$-0.32$

$(-0.66)$

$-36.7$

$(-0.29)$

$-0.01$

$(-0.15)$

$-18.4$

$(-0.06)$

26.9

(0.13)

$-9500$

$(-0.11)$
(3)

(4)

7.73

(3.69)

7.56

(3.66)

20.7

22.2

(1.34)

(1.79)

$-27.9$

$-29.9$

$(-2.51)$

$(-2.76)$
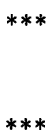

0.03

0.00

(0.66)

(0.16)

-0.16 .

$-0.16$

$(-0.06)$

$(-0.06)$

0.00

0.18

(0.00)

(0.50)

33.2

39.2

(1.49)

(1.77)

$-0.00$

$-0.00$

$(-1.18)$

$(-0.65)$

0.01

0.04

(0.05)

$(0.22)$

0.29

0.19

(0.96)

(0.56)

153

(1.74)

246

(2.67)

0.02

$-0.01$

(0.65)

(0.61)

0.04

$-0.04$

(0.40)

$(-0.51)$

$-0.13$

$-0.10$

$(-0.85)$

$(-0.47)$

$-75.4$

$(-1.71)$ 
Total rainfall *

real fertilizer price

Positive monsoon onset

Negative monsoon end

Positive frequency of rainfall days

Positive total rainfall

Chi-squared test for fertilizer variables

Chi-squared test for rainfall shock

Chi-squared test for irrigation variables

Chi-squared test for one-sided shocks

$\begin{array}{cc}-4.70 & -6.08 \\ (-0.25) & (-0.28) \\ * * * & -0.08 \\ & (-0.19) \\ & \\ * * * & 0.58 \\ & (1.87) \\ * * * & 85.6 \\ & (1.84) \\ * * * & 0.01 \\ & (0.49) \\ 26.2 & 18.2 \\ \text { value }=0.0 \%) & (\mathrm{p}-\text { value }=0.2 \%)\end{array}$

$\begin{array}{cc}\begin{array}{cc}1.3 \\ (\mathrm{p} \text {-value }=86.8 \%)\end{array} & \begin{array}{c}3.2 \\ \text { (p-value }=52.3 \%)\end{array} \\ 0.4 & 1.1 \\ \text { (p-value }=93.1 \%) & (\mathrm{p} \text {-value=76.8\%) } \\ & \\ * * * & 7.4 \\ & \text { (p-value }=11.7 \%)\end{array}$

\begin{tabular}{|c|c|}
\hline $\begin{array}{c}-0.01 \\
(-0.58)\end{array}$ & $\begin{array}{c}0.00 \\
(0.52)\end{array}$ \\
\hline$* * *$ & $\begin{array}{c}0.41 \\
(0.93)\end{array}$ \\
\hline$* * *$ & $\begin{array}{c}0.07 \\
(0.62)\end{array}$ \\
\hline$* * *$ & $\begin{array}{l}69.78 \\
(1.84)\end{array}$ \\
\hline$* * *$ & $\begin{array}{c}-0.00 \\
(-0.22)\end{array}$ \\
\hline $\begin{array}{c}113.5 \\
(p-\text { value }=0.00 \%)\end{array}$ & $\begin{array}{c}107.9 \\
\text { (p-value }=0.00 \%)\end{array}$ \\
\hline $\begin{array}{c}7.3 \\
\text { (p-value }=12.0 \%)\end{array}$ & $\begin{array}{c}7.6 \\
(p-\text { value }=10.8 \%)\end{array}$ \\
\hline $\begin{array}{c}5.2 \\
(p-\text { value }=15.7 \%)\end{array}$ & $\begin{array}{c}3.4 \\
\text { (p-value }=32.9 \%)\end{array}$ \\
\hline$* * *$ & $\begin{array}{c}16.6 \\
\text { (p-value }=0.20 \%)\end{array}$ \\
\hline
\end{tabular}


References

Antle, John M. "Economic Estimation of Producers' Risk Attributes," Journal of Agricultural Economics 71:4(1987) 505-522.

. "Nonstructural Risk Attitude Estimation," American Journal of Agricultural Economics 35:3(1989) 774-784.

Binswanger, Hans P. "Attitudes Towards Risk: Experimental Measurement in Rural India," American Journal of Agricultural Economics (1980)62:3 395-407.

"Attitudes Towards Risk: Theoretical Implications of an Experiment in Rural India,” Economic Journal 93:3 (1981) 867-889.

Feder, Gershon. "The Impact of Uncertainty in a Class of Objective Functions," Journal of Economic Theory 16(1977) 504-512.

"Farm Size, Risk Aversion, and the Adoption of New Technology Under Uncertainty," Oxford Economic Papers 32:2(1980) 263-283.

, Richard Just and David Zilberman. "Adoption of Agricultural Innovations in Developing Countries: A Survey," Economic Development and Cultural Change 33:2 (1985)

Honore, Bo E. "Trimmed LAD and Least Squares Estimation of Truncated and Censored Regression Models With Fixed Effects," Econometric 60:2 (1992) 533-565.

Intrillagator, Michael D. (1971) Mathematical Optimization and Economic Theory: Englewood Cliffs, NJ: Prentice-Hall, Inc.

Just, Richard E., and Rulon Pope. "Stochastic Specification of Production Functions and Economic Implications," Journal Of Econometrics 7:1(1977) 67-86.

- "Production Function Estimation and Related Risk Considerations," American Journal of Agricultural Economics 61:2(1979) 276-284.

Just, Richard E. and David Zilberman. "Stochastic Structure, Farm Size, and Technology Adoption in Developing Agriculture," Oxford Economic Papers 35:2(1983) 307-328.

Lamb, Russell L. "Off-farm Labor Markets and Modern Inputs in Developing Country Agriculture," unpublished Ph.D. dissertation, University of Pennsylvania, Philadelphia, PA.

Moscardi, Edgardo and Alain de Jainvry. "Attitudes Toward Risk Among Peasants: An 
Econometric Approach," American Journal of Agricultural Economics 59:4(1977) 710716.

Paxson, Christina H. "Consumption and Income Seasonality in Thailand," Journal of political Economy 101:1 (1993) 39-72.

Rose, Elaina. "Labor-Supply and Ex-Post Consumption Smoothing in a Low-Income Developing Country," mimeo, University of Washington, Seattle, 1994.

Rosenzweig, Mark R. "Risk, Implicit Contracts, and the Family in Rural Areas of Low-Income Countries," Economic Journal 98:4 (1988) 1148-1170.

and Hans Binswanger. "Wealth, Weather Risk, and the Composition and Profitability of' Agricultural Investments," Economic Journal 103 (January, 1993) 56-78.

, and Kenneth Wolpin. "Credit Market Constraints, Consumption Smoothing, and the Accumulation of Durable Production Assets in Low-Income Countries," Journal of Political Economy 101:2 (1993) 223-244.

, and Kenneth Wolpin. "Specific Experience, Household Structure, and Intergenerational Transfers: Farm Family Land and Labor Arrangements in Developing Countries," Quarterly Journal of Economics 100:3 (1985) 961-987.

, and Radwan Shaban. "Share Tenancy, Risk, and the Adoption of New Technology," mimeo, Department of Economics, University of Pennsylvania, Philadelphia, Pennsylvania, 1993.

Rothschild, Michael and Joseph E. Stiglitz. "Increasing Risk I: A Definition," Journal of Economic Theory 2 (1970) 225-243.

Rothschild, Michael and Joseph E. Stiglitz. "Increasing Risk II: Its Economic Consequences," Journal of Economic Theory 3 (1971) 66-84.

Saha, Atanu. "A two-season agricultural household model of output and price uncertainty," Journal of Development Economics 45:2(1994) 245-269.

Skoufias, Emmanuel. "Using Shadow Wages to Estimate Labor Supply of Agricultural Households," American Journal of Agricultural Economics 76:2 (1994) 215-227.

Townsend, Robert M. "Consumption Insurance: An Evaluation of Risk-Bearing Systems in LowIncome Economies," Journal of Economic Perspectives 9:3 (1994) 83-102.

Walker, James S. and John Ryan. (1990) Village and Household Economies in India's Semi-Arid Tropics. Baltimore: Johns Hopkins University Press. 
Appendix

\section{Second-Period Problem}

In the second-period problem, I begin with the first-order condition for profit maximization, equation ( $\mathrm{Al})$ :

$$
-\left[(1-\gamma)^{\lambda} \tilde{\theta}+\gamma \bar{\theta}\right] \mathrm{f}_{1}(\mathrm{X}, \overline{\mathrm{L}}-\mathrm{L})+\left(\overline{\mathrm{w}}+\tilde{\theta} \mathrm{d}^{\eta}\right)=\mathrm{O}
$$

The second-order condition for maximization requires that

$$
\left[(1-\gamma)^{\lambda \tilde{\theta}}+\gamma \bar{\theta}\right] \mathrm{f}_{11}<0
$$

which holds if and only if $(1-\gamma)^{\lambda} \tilde{\theta}+\gamma \theta>0$. Totally differentiating the first-order condition, we derive the comparative statics with respect to exogenous variables and parameters. Increases in the average wage increase second-period labor supply, ceteris paribus:

$$
\partial \mathrm{L} / \partial \overline{\mathrm{w}}=-1 /\left[(1-\gamma)^{\lambda} \tilde{\theta}+\gamma \bar{\theta}\right] \mathrm{f}_{11}>0
$$

by the second-order conditions. Likewise, consider the effect of the production shock on secondperiod labor supply:

$$
\partial \mathrm{L} / \partial \tilde{\theta}=\frac{-\left[-[1-\gamma)^{\lambda} \mathrm{f}_{1}+\mathrm{d}^{\eta}\right]}{\left[(1-\gamma)^{\lambda} \tilde{\theta}+\gamma \bar{\theta}\right] \mathrm{f}_{11}}
$$

If the shock raises the marginal productivity of labor by more than it raises the off-farm wage, e.g. $(1-\gamma)^{\lambda} f_{1}>d^{\eta}$, then $\partial L / \partial \tilde{\theta}<0$ holds, farmer's supply less labor off-farm the greater the production shock. The direct effect of irrigation on second-period labor supply is:

$$
\partial \mathrm{L} / \partial \gamma=\frac{\left[\bar{\theta}-\lambda(1-\gamma)^{\lambda-1} \tilde{\theta}\right] \mathrm{f}_{1}}{\left[(1-\gamma)^{\lambda} \tilde{\theta}+\gamma \bar{\theta}\right] \mathrm{f}_{11}}
$$

Off-farm labor supply is lower the greater is the share of irrigated land if and only if 
$\bar{\theta}>\lambda(1-\gamma)^{\lambda-1} \tilde{\theta}$; this implies that in years in which rainfall is very large, off-farm labor supply could actually increase. While this result is incidental to the nature of the modelling exercise, it is intuitive: too much rain does not increase agricultural production. Off-farm labor also responds to the quantity of fertilizer used by the farmer in the first period:

$$
\partial \mathbf{L} / \partial \mathbf{x}=\mathbf{f}_{1 \mathrm{x}} / \mathbf{f}_{11} .
$$

If fertilizer and labor input are complements in production, which is reasonable since fertilizer used raises the marginal productivity of labor, then $\partial \mathrm{L} / \partial \mathrm{x}<0$.

The effect of the exogenous variables and model parameters on the response to the production shock and the effect of fertilizer usage on various parameters of the model are also of interest. Consider first the effect of an increase in fertilizer use on the response of secondperiod labor to the rainfall shock:

$$
\partial^{2} \mathrm{~L} / \partial \tilde{\theta} \partial \mathrm{x}=\frac{(1-\gamma)^{\lambda} \mathrm{f}_{\mathrm{x} 1} \mathrm{f}_{11}-\left[(1-\gamma)^{\lambda} \mathrm{f}_{1}-\mathrm{d}^{\eta}\right] \mathrm{f}_{11 \mathrm{x}}}{\left[(1-\gamma)^{\lambda} \tilde{\theta}+\bar{\theta} \gamma\right] \mathrm{f}_{11}^{2}}
$$

The intuition of the model predicts that $\partial^{2} \mathrm{~L} / \partial \tilde{\theta} \partial \mathrm{X}<0$. A sufficient condition for this to hold is that $f_{11 x}>0$.

Now consider the effect of $y$ on the response of second-period labor supply to the rainfall shock. Recall that there is both a mean effect and a risk effect:

$$
\partial^{2} L / \partial \tilde{\theta} \partial \gamma=\frac{-\lambda(1-\gamma)^{\lambda-1} \mathrm{f}_{1}\left[(1-\gamma)^{\lambda} \tilde{\theta}+\gamma \bar{\theta}\right]-\left[(1-\mathrm{y})^{\lambda} \mathrm{f}_{1}-\mathrm{d} \eta\right]\left[\lambda(1-\gamma)^{\lambda-1} \tilde{\theta}+\bar{\theta}\right]}{\left[(1-\gamma)^{\lambda} \tilde{\theta}+\gamma \bar{\theta}\right]^{2} \mathrm{f}_{11}}
$$

which is positive if $\lambda(1-\gamma)^{\lambda-1} \tilde{\theta}+\bar{\theta}>0$. 


\section{First-Period Problem}

The first-order condition for the first-period problem is given in (A.2):

$$
\mathrm{E}_{\theta}\left\{\mathrm{U}^{\prime}\left[\left(\gamma \bar{\theta}+(1-\gamma)^{\lambda} \tilde{\theta}\right) \mathrm{f}_{\mathrm{X}}-\mathrm{q}\right]\right\}=\mathrm{O} .
$$

Rearranging terms yields

$$
\mathrm{U}^{\prime}\left[\gamma \bar{\theta} \mathrm{f}_{\mathrm{x}}-\mathrm{q}\right]+\mathrm{E}_{\theta} \mathrm{U}^{\prime}\left[(1-\gamma)^{\lambda} \tilde{\theta} \mathrm{f}_{\mathrm{x}}\right]=\mathrm{O} .
$$

With no uncertainty, the first-order condition would require $\gamma \bar{\theta} f_{x}-q=O$, which is equivalent to setting the first term in equation (7) equal to zero. The second term in (A.3) represents the effect of uncertainty on fertilizer use, and is negative, a simple proof of which follows. Recall that $\tilde{\theta}=\boldsymbol{\theta}-\bar{\theta}$ and $\mathrm{U}^{\prime}<0$, so that:

$$
\begin{aligned}
& \theta>\bar{\theta} \Rightarrow \mathrm{U}^{\prime}(\theta)<\mathrm{U}^{\prime}(\bar{\theta}) \\
& \theta<\bar{\theta} \Rightarrow \mathrm{U}^{\prime}(\theta)>\mathrm{U}^{\prime}(\bar{\theta})
\end{aligned}
$$

Multiplying (i) and (ii) by $(\theta-\bar{\theta})$, and recognizing that the inequality in (ii) reverses, yields $\left.\mathrm{U}^{\prime}(\theta)(\theta-\bar{\theta})>\mathrm{U}^{\prime}(\theta) \overline{(\theta}-\theta\right)$ which implies $\mathrm{E}_{\theta} \mathrm{U}^{\prime}(\theta)(\theta-\bar{\theta})>\mathrm{E}_{\theta} \mathrm{U}^{\prime}(\bar{\theta})(\theta-\bar{\theta})=0$.

Recall that off-farm labor supply in the second period responds to the farmer's choice of input in the first period. So when differentiating first-order conditions, it is necessary to take account of the effect of model parameters on second-period variables. Second-order conditions require that:

$$
\Delta_{1}=\mathrm{E}_{\theta} \mathrm{U}^{\prime \prime}\left[\left((1-\gamma)^{\lambda} \tilde{\theta}+\gamma \bar{\theta}\right) \mathrm{f}_{\mathrm{x}}-\mathrm{q}\right]^{2}+\mathrm{E}_{\theta} \mathrm{U}^{\prime}\left(\gamma \bar{\theta}+(1-\gamma)^{\lambda} \tilde{\theta}\right)\left[\mathrm{f}_{\mathrm{xx}}+\mathrm{f}_{\mathrm{x} 1}^{2} / \mathrm{f}_{11}\right]<0
$$

This condition requires assumptions on the technology described by the production function and the shape of the utility function. In the Cobb-Douglas case, $f_{x x}-f_{x 1}{ }^{2} / f_{11}<0$ holds if and only 
if there are decreasing returns to scale. In that case, a sufficient condition for equation (24) to hold is $\mathrm{E}_{\theta}\left\{\mathrm{U}^{\prime}\left[\gamma \bar{\theta}+(1-\gamma)^{\lambda} \tilde{\theta}\right]\right\}>0$. But by the FOC's $\mathrm{E}_{\theta}\left\{\mathrm{U}^{\prime}\left[\gamma \bar{\theta}+(1-\gamma)^{\lambda} \tilde{\theta}\right]\right\}=\overline{\mathrm{U}}^{\prime} \mathrm{q} / \mathrm{f}_{\mathrm{x}}>0$ So in the Cobb-Douglas case decreasing returns to scale are sufficient to insure that the SOC's hold. In a more general technology, we need to be careful to sign the term $f_{x x}-f_{x 1} 2 / f_{11}$.

To find the comparative statics for fertilizer demand, I totally differentiate equation (A.2) and solve for the relevant derivative. For example, consider the own-price effect on fertilizer demand:

$$
\partial X / \partial q \text { “ } \frac{\mathrm{E}_{\theta} \mathrm{U}^{\prime \prime}(-\mathrm{x})\left\{\left[(1-\mathrm{y})^{\lambda} \tilde{\theta}+\gamma \bar{\theta}\right] \mathrm{f}_{\mathrm{x}}-\mathrm{q}\right\}-\mathrm{E}_{\theta} \mathrm{U}^{\prime}}{-\Delta_{1}}
$$

The denominator in (A.5) is positive by the second-order conditions. The sign depends on the term $\mathrm{E}_{\theta}\left\{\mathrm{U} / /\left[(1-\mathrm{y})^{\lambda} \tilde{\theta}+\gamma \bar{\theta}\right] \mathrm{f}_{\mathrm{x}}-\mathrm{q}\right\}$, which depends on the third-derivative of the utility function. Assuming decreasing absolute risk aversion, we can sign this term. I apply some general results found in Feder (1977). Define $\tilde{\theta}^{*}$ by $\left[(1-\gamma)^{\lambda} \tilde{\theta}^{*}+\gamma \bar{\theta}\right] \mathrm{f}_{\mathrm{x}}-\mathrm{q}=\mathrm{O}$ and $\mathrm{R}(\tilde{\theta})=-\mathrm{U}^{\prime \prime}(\tilde{\theta}) / \mathrm{U}^{\prime}(\tilde{\theta})$. Assuming decreasing absolute risk aversion,

$$
\begin{aligned}
& \mathrm{R}(\tilde{\theta}) \leq \mathrm{R}\left(\tilde{\theta}^{*}\right) \text { for } \tilde{\theta} \geq \tilde{\theta}^{*} \\
& \mathrm{R}(\tilde{\theta}) \geq \mathrm{R}\left(\tilde{\theta}^{*}\right) \text { for } \tilde{\theta} \leq \tilde{\theta}^{*}
\end{aligned}
$$

which can be rearranged to yield:

$$
\begin{aligned}
& -\mathrm{U}^{\prime \prime}(\tilde{\theta}) \leq \mathrm{R}\left(\theta^{*}\right) \mathrm{U}^{\prime}(\tilde{\theta}) \text { for } \tilde{\theta} \geq \theta^{*} \\
& -\mathrm{U}^{\prime \prime}(\tilde{\theta}) \geq \mathrm{R}\left(\theta^{*}\right) \mathrm{U} \quad(\mathrm{p}) \text { for } \tilde{\theta} \leq \theta^{*}
\end{aligned}
$$

By definition $\left\{\left[(1-\mathrm{y})^{\lambda} \tilde{\theta}+\gamma \bar{\theta}\right] \mathrm{f}_{\mathrm{x}}-\mathrm{q}\right\} \geq(\leq)$ O for $\tilde{\theta} \geq(\leq) \theta^{*}$. Multiplying both sides of(v) 
and (vi) and taking expectations yields:

$$
\mathrm{E}_{\theta} \mathrm{U}^{\prime \prime}\left\{\left[(1-\gamma)^{\lambda} \tilde{\theta}+\gamma \bar{\theta}\right] \mathrm{f}_{\mathrm{x}}-\mathrm{q}\right\} \geq-\mathrm{R}\left(\theta^{*}\right)\left\{\mathrm{E}_{\theta} \mathrm{U}{ }^{\prime}\left\{\left[(1-\mathrm{Y})^{\lambda} \tilde{\theta}+\gamma \bar{\theta}\right] \mathrm{f}_{\mathrm{x}}-\mathrm{q}\right\}^{=} 0\right.
$$

So the first term in the numerator is negative; the second term is negative since $U^{\prime}>0$ holds everywhere.

The response of fertilizer demand to the share of irrigated land, y, is also important. Generally, irrigation is viewed as almost a prerequisite for adoption and use of modern inputs to production. Totally differentiating and rearranging equation (A.2) yields $\partial \mathrm{X} / \partial \gamma=$ :

$$
\frac{\mathrm{E}_{\theta} \mathrm{U}^{\prime \prime}\left[\left(\gamma \bar{\theta}-(1-\gamma)^{\lambda} \tilde{\theta}\right) \mathrm{f}_{\mathrm{x}}-\mathrm{q}\right]\left[\left(\bar{\theta}-\lambda(1-\gamma)^{\lambda-1} \tilde{\theta}\right) \mathrm{f}\right]+\mathrm{E}_{\theta} \mathrm{U}^{\prime}\left(\sim \sim \sim(1-\mathrm{y})^{\lambda-1} \tilde{\theta}\right) \mathrm{f}_{\mathrm{x}}-\mathrm{E}_{\theta} \mathrm{U}^{\prime}\left[\gamma \bar{\theta}-(1-\gamma)^{\lambda} \tilde{\theta}\right] \mathrm{f}_{\mathrm{xl}} \partial \mathrm{L} / \partial \gamma}{-\Delta_{1}}
$$

The denominator is positive, by the second-order conditions. The second term in the numerator is positive since $\operatorname{Cov}\left(\mathrm{U}^{\prime}, \tilde{\theta}\right)<0$. Consider the final term in the numerator:

$$
\mathrm{E}_{\theta} \mathrm{U}^{\prime}\left[\gamma \bar{\theta}+(1-\gamma)^{\lambda} \tilde{\theta}\right] \mathrm{f}_{\mathrm{xl}} \partial \mathrm{L} / \partial \gamma
$$

Substituting for $\partial \mathbf{L} / \partial \gamma$ and canceling terms yields:

$$
\mathrm{E}_{\theta} \mathrm{U} \cdot\left[\sim-\lambda(1-\gamma)^{\lambda-1} \tilde{\theta}\right] \frac{\mathrm{f}_{\mathrm{xl}}}{\mathrm{f}_{\mathrm{ll}}} \mathrm{f}_{1}
$$

which is positive if $f_{x l}>0$. To show that the first term is positive as well, I need to prove that $\mathrm{E}_{\theta} \mathrm{U}^{\prime \prime}\left[\left(\gamma \bar{\theta}+(1-\gamma)^{\lambda \tilde{\theta}}\right) \mathrm{f}_{\mathrm{x}}-\mathrm{q}\right] \tilde{\theta}<0$. But I know that

$$
\begin{gathered}
\operatorname{sign}\left\{\mathrm{E}_{\theta} \mathrm{U}^{\prime \prime}\left[\left(\gamma \bar{\theta}+(1-\gamma)^{\lambda} \tilde{\theta}\right) \mathrm{f}_{\mathrm{x}}-\mathrm{q}\right] \tilde{\theta}\right\}= \\
\operatorname{sign}\left\{\mathrm{E}_{\theta} \mathrm{U}^{\prime \prime}\left[\left(\gamma \bar{\theta}+(1-\mathrm{y})^{\lambda} \tilde{\theta}\right) \mathrm{f}_{\mathrm{x}}-\mathrm{q}\right]\left[(1-\gamma)^{\lambda} \mathrm{f}_{\mathrm{x}} \tilde{\theta}+\gamma \bar{\theta} \mathrm{f}_{\mathrm{x}}-\mathrm{q}-\left(\gamma \bar{\theta} \mathrm{f}_{\mathrm{x}} \mathrm{q}\right)\right]\right\}
\end{gathered}
$$

Rearranging yields:

$$
\operatorname{sign}\left\{\mathrm{E}_{\theta} \mathrm{U}^{\prime \prime}\left[\left(\gamma \bar{\theta}+(1-\gamma)^{\lambda} \tilde{\theta}\right) \mathrm{f}_{\mathrm{x}}-\mathrm{q}\right]^{2}+\sigma \mathrm{kE}_{\theta} \mathrm{U}^{\prime \prime}\left[\left(\gamma \bar{\theta}+(1-\mathrm{y})^{\lambda}\right) \mathrm{f}_{\mathrm{x}}\right]\right.
$$


where $\mathrm{k}>0$ is a function of model parameters and $\sigma=\operatorname{Cov}\left(\mathrm{U}^{\prime}, \tilde{\theta}\right)<0$. The first term is negative, since $U^{\prime}$ is negative everywhere by assumption, and the second term is negative since $\sigma<0$ and $\mathrm{E}_{\theta} \mathrm{U}^{\prime /}\left[\left(\gamma \bar{\theta}+(1-\gamma)^{\lambda} \tilde{\theta}\right)-\mathrm{q}\right]>0$ by (iii) - (vi). QED.

The response of fertilizer demand to $\mathrm{d}$, which captures the isolation of the local labor market is also important. Totally differentiating and rearranging yields

$$
\operatorname{ax} / \mathrm{ad} \text { “ } \frac{\left.\mathrm{E}_{\theta} \mathrm{U}^{\prime \prime}\left[(1-\gamma)^{\lambda} \tilde{\theta}+\gamma \sim\right] \mathrm{f}_{\mathrm{x}}-\mathrm{q}\right] \tilde{\theta} \eta \mathrm{d}^{\eta-1} \mathrm{~L}-\mathrm{E}_{\theta} \mathrm{U}^{\prime}\left[\left(\gamma \bar{\theta}+(1-\gamma)^{\lambda} \tilde{\theta}\right) \mathrm{f}_{\mathrm{x} 1} \partial \mathrm{L} / \partial \mathrm{d}\right\}}{-\Delta_{1}}
$$

The first term is negative by the argument presented above. To sign the second term, substitute $\partial \mathrm{L} / \partial \mathrm{d}:$

$$
-\mathrm{E}_{\theta} \mathrm{U}^{\prime} \tilde{\theta} \mathrm{f}_{\mathrm{xl}}>0
$$

if $\mathrm{f}_{\mathrm{xl}}>0$.

Finally, consider the response of fertilizer demand to increases in risk, as measured by a mean-preserving spread in the distribution of the purely random component of weather, $\tilde{\theta}$. A similar question has been addressed in a more general framework by Rothschild and Stiglitz (1971) and by Feder (1977). We can think of replacing $\tilde{\theta}$ with $\tilde{\theta} * \mathbf{r}$. So a mean-preserving spread in the distribution of weather shock variable corresponds to an increase in $r$, and we want to determine the sign of $\partial \mathrm{x} / \partial \mathrm{r}$. To find the derivative, we replace $\tilde{\theta}$ with $\tilde{\theta} * \mathrm{r}$. Then totally differentiate the first-order condition with respect to $r$ to find the comparative static results:

$$
\partial X / \partial r=\frac{E_{\theta}\left\{\mathrm{U}^{\prime \prime}\left[(1-\mathrm{y} \gamma)^{\lambda} \tilde{\theta}\right) \mathrm{f}(\cdot)+\tilde{\theta} \mathrm{d}^{\eta} \mathrm{L}\right]\left[\left(\gamma \bar{\theta}+(1-\mathrm{y})^{\lambda} \mathrm{r} \tilde{\theta}\right) \mathrm{f}_{\mathrm{x}}-\mathrm{q}\right]+\mathrm{E}_{\theta} \mathrm{U}^{\prime}(1-\gamma)^{\lambda} \tilde{\theta} \mathrm{f}_{\mathrm{x}}}{-\Delta_{1}}
$$


The denominator is positive by SOC, and the second term is negative by the concavity of the utility function and the fact that marginal product of fertilizer is positive. The sign of the first term depends on the relative impact of a production shock on farm production versus the impact on the wage in the wage labor market. If the term $(1-\gamma)^{\lambda} f(\cdot)+d^{\eta} L>0$, then the effect can not be signed a priori. 